\title{
The Development Analysis of Sharia Bank in Province of Aceh in Last Decade
}

\author{
Cut Delsie Hasrina ${ }^{1}$ and Azlim and Yusri ${ }^{1}$ \\ \{cut.hasrina@yahoo.com\} \\ ${ }^{1}$ Department of Accounting, Abulyatama University Lampoh Keude - Aceh Besar, Indonesia
}

\begin{abstract}
The aim of this study is to provide a descriptive analysis of sharia commercial bank development in Province of Aceh during the last decade. This study collected and analized literatures to examine the written sources of scientific journals, books, encyclopedias, scientific articles and other sources that are relevant and related to the studied object. The object of this study is the form of texts or writings that describe and explain about the development of sharia commercial banks in Province of Aceh, Indonesia. The result of this study indicated that the development of sharia commercial bank in Province of Aceh has been increasing in the last decade. The number of sharia commercial banks who run their bussiness in Province of Aceh increased from 2 (two) banks in year of 2007 to be 10 (ten) banks in 2012 and finally became 12 (twelve) banks in 2017. The number of asset values always increased year by year, however sometimes the value of saving and deposit had some fluctuation of value on certain year but the value of saving and deposit for total of one decade increased. The number of credit values especially consumption credit value also increased significanly year by year. One of conventional bank namely Bank Aceh has been converted to sharia systema s Bank Aceh Syariah in 2016 and has been operating as the biggest sharia bank in Province of Aceh.
\end{abstract}

Keywords: sharia bank, conventional bank, banking, asset and saving

\section{Introduction}

Banking institutions in Indonesia have a very important and significant role for society and industry both for large, medium and small industries to establish the sustainable development process of the Republic of Indonesia. This is because the community and industry need a bank either for strengthening capital or saving money. To meet and improve the needs of the community, especially those who are moslem and provide a sense of security, comfortable transactions, so that the presence of islamic or sharia banks is one solution to increase trust in banking activities, especially in Indonesia.

Sharia banks are banks based on islamic economic systems (Faridah, 2011). The islamic or sharia economic system is currently being discussed in Indonesia. Sharia bank was initially established and developed as a response from economic groups and moslem banking practitioners who seek to accommodate the insistence of various parties who want the availability of financial transaction services carried out in line with the moral values and principles of islamic/sharia manners (Rasyid, 2018).

The development of sharia banks in Indonesia basically have enormous potential and opportunities (Marimin, Romdhoni and Fitria, 2015). Growth of bank assets proven that sharia banks are a bank model that is ideal for encouraging the economic progress in Indonesia. However, in terms of service quality, sharia banks must improve their services compared with conventional banks. 
The establishment of sharia banks in Indonesia began with the opening of Bank Muamalat Indonesia (BMI) as the first syariah bank in 1992. Until next 6 years after its first opening, there was only one sharia bank operating in Indonesia. During the period of 1992 to 1998, there was no known islamic banking system, which was only recognized by banks with the principle of profit sharing (Indonesia, 1992). This resulted in stagnating the development of sharia banking in Indonesia during this period. After the issuance of a new regulation that accommodate regulations concerning sharia banks (Indonesia, 1998) and supported by the Bank Indonesia regulation (Indonesia, 1999), then other sharia banks were born and developed rapidly. Since then the operation of the islamic banking system in Indonesia has begun in the framework of the dual banking system which is carried out jointly, namely the islamic banking system and the conventional banking system. Both of these systems are implemented in synergy to support the mobilization of public funds more broadly and developing to improve the ability of financing for various sectors of the national economy. With the implementation of Sharia Banking Regulation concerning to sharia banking [7], the development of sharia banks in the future has greater business opportunities in Indonesia. With the growth of sharia banks in Indonesia, the sharia banks in Aceh Province have also developed. The first sharia bank in Aceh Province was Bank Muamalat Indonesia. After then islamic bank continued growing and developing in Aceh Province both sharia commercial banks, sharia business units and sharia rural banks. The development of sharia commercial banks is also supported by the implementation of islamic shari'a law in the Province of Aceh, as well as the Indonesian people are also now more aware of riba when using conventional bank services.

With the increasing the enthusiasm of the people of Aceh Province, who are mostly moslems to use islamic banking services and based on the development of sharia banks, both sharia commercial banks, sharia business units and sharia rural banks, the authors were interested in conducting research related to sharia banking to see how the development of sharia commercial banks in Aceh Province. This research was limited to the development of sharia commercial banks for the last decade (2007-2017).

\section{Literature Review}

\subsection{Definition of Sharia Banks}

According to Sharia Banking Regulation (Indonesia, 2008), islamic or sharia banking is all things related to islamic banks and sharia business units which include institutions, business activities, up to the process of implementing its business activities. Sharia banks are banks that carry out business activities based on sharia principles or islamic law principles which are regulated in the fatwa of the Indonesian Ulema Council such as the principles of justice and balance ('adl wa tawazun), kemaslahatan (maslahah), universalism (alamyah) and do not contain gharar, maysir, riba and illicit objects (OJK, 2018).

\subsection{Function of Sharia Bank}

According to (Antonio, 2010), the function of sharia banks is divided into four, namely:

- The function of bank as investment management, sharia bank acts as investment manager of fund owners (shahibul maal) from collected funds (commonly called depositors/savers). 
- The function of the bank as an investment, sharia bank invests the stored funds (bank owner's funds or investment account funds) by using investment tools in accordance with the sharia.

- Functions of sharia bank as financial services. Islamic bank can also offer various other financial services based on fee based in a representative or leasing contract. For example: warranty, wire transfer, L/C and others.

- Functions of sharia bank as social services. Islamic banking requires carrying out social services that can be through qardh funds, zakat funds or social funds in accordance with islamic rules.

\section{Research Methodology}

The data collection methods that used in this study included: (1). Through library review (2). Accessing related websites and sites and (3). Collecting data directly through Bank Indonesia of Banda Aceh branch office. Literature research is one way to obtain data by reading literature and books related to the problems studied. While the data needed to be analyzed in this study was obtained directly from the Statistik Perbankan Syariah (SPS) website which can be accessed through their website (StatistikPerbankan Syariah, 2018) and others data obtained from Bank Indonesia of Banda Aceh branch office. Data collected includes the number of sharia commercial banks in Indonesia and in Aceh Province year to year, the number of assets, the amount of funds from third parties and the amount of financing ofall sharia commercial banks that are operating in Aceh Province. The data from sharia commercial banks in the Province of Aceh were then tabulated in tables and figures and analyzed to understand the development of sharia commercial banks year to year during the period 2007 - 2017 in Aceh Province.

\section{Results And Discussion}

Bank Muamalat Indonesia (BMI) that was established in 1991 was the first islamic bank in Indonesia. The bank was initiated by the Indonesian Ulema Council, the Association of Indonesian Moslem Scholars (ICMI), Moslem businessmen and government. Unfortunately, the bank was less popular and its performance was stagnant, but it was only after the economic crisis and reformation, Bank Muamalat has begun to be considered by customers (Marimin, Romdhoni and Fitria, 2015).

Bank Indonesia of Banda Aceh branch office assessed that islamic banking business has the potential to grow in Aceh Province. Aceh has many components to support the progress of the islamic banking business such as in terms of natural wealth and the Special Economic Zone (KEK) of Arun. In addition, Aceh Province has the largest APBN allocation in Sumatra Island for infrastructure development and also receives the sixth largest APBD in Indonesia. In addition, Aceh also has a complete tourism potential from mountains, sea to religious tourism (Ganto, 2018).

During 2007 to 2017 the sharia banks in Aceh Province developed rapidly. This can be seen in terms of the increase number of sharia commercial banks in Aceh Province as can be seen in the following figure. 


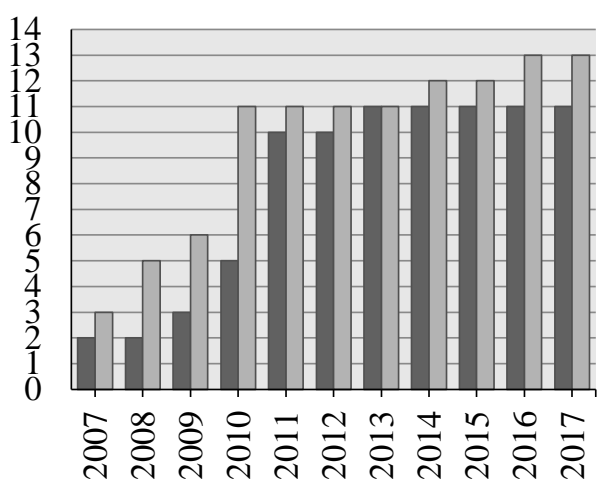

Number of sharia commercial banks in Aceh
Province
$\square$ Number of sharia commercial banks in Indonesia

Fig. 1. Number of sharia commercial banks in Aceh Province and in Indonesia in 2007 2017

Fig. 1 shows that the number of sharia commercial banks in Aceh Province continued to increase in the last ten years (2007 - 2017). There were only 2 (two) sharia commercial banks in 2007, namely PT. Bank Muamalat Indonesia and PT. Bank Syariah Mandiri out of 3 (three) sharia commercial banks that have been established in Indonesia (PT. Bank Syariah Mandiri, PT. Bank Mega Syariah and PT. Bank Muamalat Indonesia). Fig. 1 shows that each year the number of sharia commercial banks in Aceh Province increased with the increase of sharia commercial banks in Indonesia.

After 10 (ten) years (in 2017) the number of sharia commercial banks in Aceh Province increased by 9 (nine) banks, to be 11 (eleven) banks namely: PT. Bank Aceh Syariah, PT. Bank Muamalat Indonesia, PT. Bank BRISyariah, PT. Bank BNI Syariah, PT. Bank Syariah Mandiri, PT. Bank Mega Syariah, PT. Panin Dubai Syariah Bank, PT. Bank Syariah Bukopin, PT. BCA Syariah, PT. Maybank Syariah Indonesia and PT. Bank Tabungan Pensiunan Nasional Syariah. While Sharia commercial banks operating in Indonesia in 2017 consisted of 13 (thirteen) banks, namely PT. Bank Aceh Syariah, PT. Bank Muamalat Indonesia, PT. Bank Victoria Syariah, PT. Bank BRI Syariah, PT. Bank Jabar Banten Syariah, PT. Bank BNI Syariah, PT. Bank Syariah Mandiri, PT. Bank Mega Syariah, PT. Panin Dubai Syariah Bank, PT. Bank Syariah Bukopin, PT. BCA Syariah, PT. Maybank Syariah Indonesia and PT. Bank Tabungan Pensiunan Nasional Syariah. In other words, only 2 (two) sharia commercial banks that have not operated in Aceh Province, namely PT. Bank Victoria Syariah and PT. Bank Jabar Banten Syariah.

Table 1. Development Of The Number And Percentage Of Sharia Commercial Banks Operating In Aceh Province During 2007 - 2017

\begin{tabular}{|c|c|c|c|}
\hline Year & $\begin{array}{c}\text { Number of } \\
\text { sharia } \\
\text { commercial } \\
\text { banks in Aceh } \\
\text { Province }\end{array}$ & $\begin{array}{c}\text { Percentage of } \\
\text { sharia } \\
\text { commercial } \\
\text { banks in Aceh } \\
\text { Province (\%) }\end{array}$ & $\begin{array}{c}\text { Number of sharia } \\
\text { commercial banks } \\
\text { in Indonesia }\end{array}$ \\
\hline
\end{tabular}




\begin{tabular}{lrrr}
\hline 2007 & 2 & 67 & 3 \\
\hline 2008 & 2 & 40 & 5 \\
\hline 2009 & 3 & 50 & 6 \\
\hline 2010 & 5 & 45 & 11 \\
\hline 2011 & 10 & 91 & 11 \\
\hline 2012 & 10 & 91 & 11 \\
\hline 2013 & 11 & 100 & 11 \\
\hline 2014 & 11 & 92 & 12 \\
\hline 2015 & 11 & 92 & 12 \\
\hline 2016 & 11 & 85 & 13 \\
\hline 2017 & 11 & 85 & 13 \\
\hline & Source : Processed data of SPS and Bank Indonesia
\end{tabular}

Based on Table 1, it can be identified that the development of islamic commercial banks in Aceh Province was very good. One of the causes of the increase of sharia commercial banks in Aceh Province is that the population of Aceh Province, which is almost $100 \%$ moslem, realized that saving in conventional commercial banks is riba, so they are very enthusiastic to save their money in sharia commercial banks. Table 1 also explains that after the presence of 2 sharia commercial banks namely PT. Bank Muamalat Indonesia and PT. Bank Syariah Mandiri in 2007 and 2008, the development of sharia commercial banks in Aceh Province gradually grew that marked by the increase of sharia commercial banks to be 3 (three) banks in 2009 , which was also in line with the increase the number of sharia commercial banks in Indonesia that had become 6 (six) banks in 2009 from the previously 3 (three) banks in 2007 and 5 (five) banks in 2009. In 2009, the percentage of sharia commercial banks operating in Aceh Province was half $(50 \%)$ of those operating in Indonesia. Of course this percentage is quite good compared to $40 \%$ in 2008 .

In 2010, the development of sharia commercial banks in Indonesia experienced a very rapid development compared to the previous year (2007-2009), where in 2010 in Indonesia there were 11 (eleven) sharia commercial banks or 2 times more than year of 2008 - 2009 . From this data it can be said that the number of sharia commercial banks in Indonesia experienced a sharp increasing in 2010. However, this rapid development has not yet taken place directly on the same year in Aceh Province where it can occur due to the process of infrastructure development and maturation and the development of the system from the sharia commercial bank itself and also requires a year or more to be stabilized. This can be seen from Table 1 where since 2011 the development of sharia commercial banks in the Province of Aceh has experienced a very rapid development, namely from the number of 5 (five) banks in 2010 to be twice in 2011, namely to be 10 (ten) banks (increase up $100 \%$ ). It can be said statistically that in 2011 the percentage of sharia commercial banks in Aceh Province compared to in Indonesia became very large, namely $91 \%$ compared to the previous year that was only 45\%. Between 2010 and 2013 the number of sharia commercial banks in Indonesia was same that only 11 sharia commercial banks. The addition of one new sharia commercial bank occurred on the following year with the establishment of PT. Bank Tabungan Pensiunan Nasional Syariah in 2014 and PT. Bank Aceh Syariah in 2016. PT. Bank Aceh Syariah was previously a conventional bank of PT. Bank Aceh. The Aceh Provincial Government suspended the operation of conventional banks following the passing of regional regulations or what is often called the Qanun, namely Hukum Jinayah Qanun [13] and Sistem Produk Jaminan Halal Qanun [14]. The closure of the conventional bank was carried out based on the conventional bank system that was considered to be riba, whereas it was contradictory to the 
Acehnese law that applied the shari'a perfectly (kaffah) [15]. Meanwhile, from 2013 to 2015 the number of sharia commercial banks in Aceh Province did not increase. There were still 11 (eleven) banks even though there were already 12 (twelve) sharia commercial banks in Indonesia. The new addition occurred in 2016, when Bank Aceh changed from a conventional system to sharia symtem and the name of the bank became PT. Bank Aceh Syariah.

Table 1 shows that sharia commercial banks in Aceh Province continued growing year by year. One example of a significant development was when the Bank of Aceh changed to Bank Aceh Syariah on 19 September 2016 based on the Decree of the OJK Board of Commissioners Number. KEP-44/D.03/2016 dated September 1, 2016 regarding the granting of permits for changes in business activities of conventional commercial banks to become sharia commercial banks of PT Bank Aceh Syariah [16]. The idea of converting Bank Aceh from a conventional bank to sharia bank was one of the monumental breakthroughs carried out by the Government of Aceh as a major shareholder with district/city governments as other shareholders to build an islamic-based economic system so that it was free of riba. Conversion options are also a strategic step in improving the performance of Bank Aceh in the future long term [16]. After being transformed into Bank Aceh Syariah, Bank Aceh Syariah recently won the Infobank Award 2018 and received a 'very good' award for financial performance in 2017. After two years of conversion into a sharia commercial bank, the financial performance of Bank Aceh Syariah continued to show a positive trend. The Infobank Award 2018 is one of the proofs of the consistency of Bank Aceh as a Regional Bank that is increasingly being calculated at the level of the national sharia commercial bank after converting to Islamic banks two year ago. This was stated by Bank Aceh Corporate Secretary Mr. Amal Hasan in a newspaper, stating that "the conversion made by Bank Aceh is the right decision to improve populist-based regional economy with the concept of Islamic economics and we hope that other banks can follow in the footsteps of Bank Aceh in order to advance the system Islamic economy in Indonesia". In addition, the conversion made by Bank Aceh continued to show a positive trend not only in terms of financial performance as well as in terms of its existence which is certainly supported by loyal customers of the Bank Aceh and the people of Aceh. For the period of December 2017 total assets reached 22.7 trillion rupiah with profit profitability of 532 billion rupiah while total financing reached 12.84 trillion rupiah, total deposits reached 18.50 trillion rupiah [17]. In general, the financial performance at the end of 2017 was very encouraging [18]. Another example of the increasing development of sharia commercial banks in Aceh is starting on December 11, 2017, all services and operational activities of Permata Bank's conventional of Banda Aceh branch office are officially closed. While all services and operational activities of the Permata Syariah Bank office in Banda Aceh continued to operate as usual (Permata Bank Tutup Cabang Konvensional di Banda Aceh, Dialihkan ke Syariah Serambi Indonesia, 2017). Apart from the above indicators, the development of sharia commercial banks in Aceh Province can also be seen from Table 2 below.

Table 2. Development of Assets, Third Party Funds and Financing of Sharia Commercial Banks in Aceh Province (in millions Rupiah)

\begin{tabular}{|c|c|c|c|c|c|c|c|c|c|c|c|}
\hline Parameter & 2007 & $\begin{array}{l}200 \\
8\end{array}$ & $\begin{array}{l}200 \\
9\end{array}$ & 2010 & 2011 & 2012 & 2013 & 2014 & 2015 & 2016 & 2017 \\
\hline \multicolumn{12}{|l|}{ Assets } \\
\hline Quarter of 1, & 4.797. & 035.77 & 6.997 & .473 .78 & 12.199. & 15.440 . & 19.338. & 839.77 & 19.461. & & 24.933. \\
\hline 2,3 and 4 & 543 & 2 & .459 & 9 & 664 & 000 & 670 & 1 & 000 & $\begin{array}{r}59.073 .8 \\
72\end{array}$ & 566 \\
\hline
\end{tabular}




\begin{tabular}{|c|c|c|c|c|c|c|c|c|c|c|c|}
\hline Parameter & 2007 & $\begin{array}{l}200 \\
8\end{array}$ & $\begin{array}{l}200 \\
9\end{array}$ & 2010 & 2011 & 2012 & 2013 & 2014 & 2015 & 2016 & 2017 \\
\hline Giro Wadiah & $\begin{array}{r}1.415 . \\
640 \\
\end{array}$ & $\begin{array}{r}456.5 \\
93 \\
\end{array}$ & $\begin{array}{r}819.4 \\
06 \\
\end{array}$ & 49.862 & $\begin{array}{r}1.146 .8 \\
00 \\
\end{array}$ & $\begin{array}{r}1.446 .5 \\
49 \\
\end{array}$ & $\begin{array}{r}2.125 .5 \\
88 \\
\end{array}$ & 07.050 & $\begin{array}{r}1.534 .0 \\
00 \\
\end{array}$ & $\begin{array}{r}10.101 .1 \\
44 \\
\end{array}$ & $\begin{array}{r}26.466 . \\
833 \\
\end{array}$ \\
\hline $\begin{array}{l}\text { Deposito } \\
\text { Mudharabah }\end{array}$ & $\begin{array}{r}1.257 . \\
111 \\
\end{array}$ & $\begin{array}{r}10.38 \\
4 \\
\end{array}$ & $\begin{array}{r}1.065 \\
.634 \\
\end{array}$ & $\begin{array}{r}038.19 \\
3 \\
\end{array}$ & $\begin{array}{r}1.807 .2 \\
74 \\
\end{array}$ & $\begin{array}{r}2.313 .0 \\
82 \\
\end{array}$ & $\begin{array}{r}2.792 .3 \\
11 \\
\end{array}$ & $\beta 42.570$ & $\begin{array}{r}5.329 .0 \\
00 \\
\end{array}$ & $\begin{array}{r}14.963 .7 \\
04 \\
\end{array}$ & $\begin{array}{r}26.540 . \\
545 \\
\end{array}$ \\
\hline $\begin{array}{l}\text { Mudharabah } \\
\& \quad \text { Wadiah } \\
\text { Saving }\end{array}$ & $\begin{array}{r}1.420 . \\
630\end{array}$ & $\begin{array}{r}378.6 \\
25\end{array}$ & $\begin{array}{r}1.970 \\
.442\end{array}$ & $\begin{array}{r}152.48 \\
2\end{array}$ & $\begin{array}{r}3.177 .4 \\
16\end{array}$ & $\begin{array}{r}3.471 .4 \\
44\end{array}$ & $\begin{array}{r}3.810 .3 \\
16\end{array}$ & 52.061 & $\begin{array}{r}6.819 .0 \\
00\end{array}$ & $\begin{array}{r}17.197 .1 \\
96\end{array}$ & $\begin{array}{r}28.072 . \\
285\end{array}$ \\
\hline \multicolumn{12}{|l|}{ Financing } \\
\hline $\begin{array}{l}\text { Working } \\
\text { Capital }\end{array}$ & $\begin{array}{r}220.64 \\
5\end{array}$ & $\begin{array}{r}72.73 \\
3 \\
\end{array}$ & $\begin{array}{r}945.9 \\
78\end{array}$ & $\begin{array}{r}461.99 \\
4\end{array}$ & $\begin{array}{r}2.549 .9 \\
25\end{array}$ & $\begin{array}{r}2.917 .7 \\
43\end{array}$ & $\begin{array}{r}3.290 .1 \\
24\end{array}$ & 537.906 & $\begin{array}{r}1.960 .0 \\
00\end{array}$ & $\begin{array}{r}3.776 .01 \\
1\end{array}$ & $\begin{array}{r}1.344 .0 \\
02\end{array}$ \\
\hline Investment & $\begin{array}{r}101.83 \\
6 \\
\end{array}$ & $\begin{array}{r}75.02 \\
3 \\
\end{array}$ & $\begin{array}{r}279.3 \\
45 \\
\end{array}$ & 22.570 & $\begin{array}{r}503.33 \\
7 \\
\end{array}$ & $\begin{array}{r}737.86 \\
7 \\
\end{array}$ & $\begin{array}{r}889.84 \\
6 \\
\end{array}$ & 31.829 & $\begin{array}{r}775.00 \\
0\end{array}$ & 832.180 & $\begin{array}{r}280.74 \\
9 \\
\end{array}$ \\
\hline Consumption & $\begin{array}{l}410.35 \\
4\end{array}$ & $\beta 4.28$ & $\begin{array}{l}1.628 \\
.517 \\
\end{array}$ & 045.83 & \begin{tabular}{|l}
5.584 .7 \\
83
\end{tabular} & $\begin{array}{l}6.717 .6 \\
73\end{array}$ & \begin{tabular}{|l}
7.476 .2 \\
17 \\
\end{tabular} & 27.572 & \begin{tabular}{|l}
9.409 .0 \\
00
\end{tabular} & $\begin{array}{l}27.580 .6 \\
60\end{array}$ & $\begin{array}{l}11.716 . \\
224\end{array}$ \\
\hline
\end{tabular}

Source : Processed data of Bank Indonesia [12]

From the Table 2 we found three important things in assessing the performance of a bank, namely:

- Assets

Assets are an important part of a company. With the assets owned by the company, businesses can continue to operate smoothly. From Table 2 it can be seen that starting from 2007 to 2017 assets of sharia commercial banks increased, this is one indication that the development of sharia commercial banks in Aceh Province is headed in a good direction.

- Fund from Third Party

According to (Kasmir, 2014), third party fund is funds that come from the public/community and are the most important source of funds for bank operations. Judging from the above table, third party funds consist of wadiah demand deposits, mudharabah deposits and savings. The numbers listed on the wadiah demand deposit experienced an increase and decrease, but the increase and decrease were not too significant that indicating Acehnese who used the wadiah deposit service were sometimes in a few numbers and sometime in many numbers of customers. As for mudaraba deposits increased every year, even from 2014 the amount of these deposits increased significantly. This shows that the public trust in using deposit services at sharia commercial banks continues to increase. With the increase in mudharabah deposits each year, sharia banks continue to grow. Other third party funds are savings, where from Table 2 it can be seen that sharia commercial bank savings continue to increase significantly each year. The increasing development of savings showed that the public interest in saving in sharia commercial banks is getting better which automatically shows that sharia commercial banks are increasing in Aceh Province.

- Financing

Financing can also be used as an indicator to see the development of sharia commercial banks. From Table 2 it can be seen that the financing of working capital, investment and consumption has increased every year, especially consumption financing. This shows that the development of sharia commercial banks also increased due to the public's trust in taking financing at sharia commercial banks as well. 


\section{Conclusion}

The number of sharia commercial banks in Aceh Province has increased from year to year from only 2 (two) banks in 2007 to 12 (twelve) banks in 2017. Besides the growing number of sharia commercial banks, the development of sharia commercial banks in Aceh Province is also growing rapidly which was marked by the increase of assets, third party funds and the financing from these 12 (twelve) sharia commercial banks operating in Aceh Province over the past decade.

\section{References}

[1] Antonio, M. S. (2010) Bank Syariah Dari Teori ke Praktek. Jakarta: Gema Insani.

[2] Faridah, A. (2011) Sistem Ekonomi Indonesia. Surakarta: Pustaka Setia.

[3] Ganto, A. (2018) Meningkatkan Daya Saing Bank Syariah. Available at: http://aceh.tribunnews.com/2018/03/01/meningkatkan-daya-saing-banksyariah?page=all). (Accessed: 7 January 2019).

[4] Indonesia, P. R. (1992) Undang-Undang Nomor 7 Tahun 1992.

[5] Indonesia, P. R. (1998) Undang-undang Republik Indonesia No 10 Tahun 1998.

[6] Indonesia, P. R. (1999) Undang-Undang no 23 Tentang Bank Indonesia.

[7] Indonesia, P. R. (2008) 'UU Nomor 21 Tahun 2008 Tentang Perbankan Syariah', Undang Undang Republik Indonesia. doi: 10.1017/CBO9781107415324.004.

[8] Kasmir (2014) Bank Dan Lembaga Keuangan Lainnya. Yogyakarta: Raja Grafindo.

[9] Marimin, A., Romdhoni, A. H. and Fitria, T. N. (2015) 'Perkembangan Bank Syariah di Indonesia', Jurnal Ilmiah Ekonomi Islam, 1(2), pp. 75-87. doi: 10.29040/jiei.v1i02.30.

[10] OJK (2018) Saham syariah, Otoritas Jasa Keuangan. doi: 10.1098/rspb.2008.0142.

[11] Permata Bank Tutup Cabang Konvensional di Banda Aceh, Dialihkan ke Syariah Serambi Indonesia (2017). Available at: http://aceh.tribunnews.com/2017/12/04/permata-bank-tutup-cabang-konvensional-dibanda-aceh-dialihkan-ke-syariah (Accessed: 7 January 2019).

[12] Rasyid, A. (2018) Perkembangan Lembaga Perbankan dan Keuangan Syariah di Indonesia. Available at: http://business-law.binus.ac.id/2018/07/03/perkembanganlembaga-perbankan-dan-keuangan-syariah-di-indonesia/ (Accessed: 7 January 2019).

[13] StatistikPerbankan Syariah (2018). Available at: https://www.ojk.go.id/id/kanal/syariah/data-dan-statistik/statistik-perbankansyariah/Documents/Pages/Statistik-Perbankan-Syariah---Oktober-2018/SPS 2018.pdf (Accessed: 7 January 2019). 